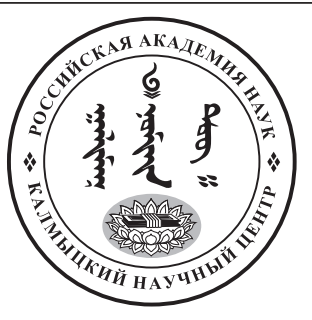

Published in the Russian Federation

Oriental Studies (Previous Name: Bulletin of the Kalmyk Institute

for Humanities of the Russian Academy of Sciences)

Has been issued as a journal since 2008

ISSN: 2619-0990; E-ISSN: 2619-1008

Vol. 13 , Is. 3, pp. 620-628, 2020

DOI: $10.22162 / 2619-0990-2020-49-3-620-628$

Journal homepage: https://kigiran.elpub.ru

УДК 294.3

DOI: 10.22162/2619-0990-2020-49-3-620-628

\title{
Новый фрагмент санскритской Саддхармапундарика-сутры из Хотана
}

\section{Артем Владимирович Мешезников}

${ }^{1}$ Институт восточных рукописей РАН (д. 18, Дворцовая наб., 191186 Санкт-Петербург, Российская Федерация)

младший научный сотрудник

(iD) 0000-0002-8883-1284. E-mail: mesheznikoff@yandex.ru

(C) КалмНЦ РАН, 2020

(C) Мешезников А. В., 2020

Аннотация. Введение. Собрание санскритских рукописей Лотосовой сутры является, пожалуй, одним из самых богатых в Сериндийском фонде Института восточных рукописей РАН (27 шифров). Основная часть фрагментов санскритской Лотосовой сутры из Сериндийского собрания относится к центральноазиатской редакции, в том числе знаменитая кашгарская рукопись Н. Ф. Петровского (SI 1925/27), являющаяся самой пространной версией сутры (около 400 листов) и ядром коллекции рукописей, содержащих санскритский текст «Саддхармапундарики». Большинство санскритских рукописей Лотосовой сутры в собрании Сериндийского фонда были составлены в южных оазисах Таримского бассейна, выполнены в формате потхи тушью на бумаге и записаны южнотуркестанским брахми. По палеографическим данным эти рукописи могут быть условно датированы VIII-IX вв. н. э. Целью статьи является введение в научный оборот нового фрагмента санскритской Лотосовой сутры из Сериндийского фонда Института восточных рукописей РАН. Публикуемый фрагмент, хранящийся под шифром SI 6584, удалось идентифицировать сравнительно недавно. Он представляет собой отрывок из XVIII главы Лотосовой сутры ('Глава, повествующая о религиозных заслугах, [обретаемых благодаря] радостной сопричастности [Дхарме]', «Anumodanāpuṇyanirdeśaparivartạı»). По палеографическим и кодикологическим характеристикам исследуемый фрагмент очень близок к другой ранее опубликованной рукописи Лотосовой сутры, хранящейся в Сериндийском собрании под шифром SI 1934. В статье приводится описание внешних особенностей обеих рукописей, а также транслитерация, перевод и сопоставление фрагмента SI 6584 с другими известными текстами Лотосовой сутры. В качестве иллюстративного материала в статью включено факсимильное воспроизведение фрагмента SI 6584. Bыводы. Как удалось установить при сопоставлении с другими текстами Лотосовой сутры, фрагмент SI 6584 относится к центральноазиатской редакции «Саддхармапундарики» и практически идентичен тексту кашгарской рукописи Н. Ф. Петровского (л. 335b-337a). 
Ключевые слова: буддизм, санскритские рукописи, Лотосовая сутра, Хотан, Сериндийский фонд

Для цитирования: Мешезников А. В. Новый фрагмент санскритской Саддхармапундарика-сутры из Хотана // Oriental Studies. 2020. T. 13. № 3. С. 620-628. DOI: 10.22162/2619-09902020-49-3-620-628

UDC 294.3

DOI: $10.22162 / 2619-0990-2020-49-3-620-628$

\title{
New Fragment of Sanskrit Saddharmapuṇḍarīka Sūtra from Khotan
}

\author{
Artem V. Mesheznikov ${ }^{1}$
}

${ }^{1}$ Institute of Oriental Manuscripts of the RAS (18, Dvortsovaya Emb., St. Petersburg 191186, Russian Federation)

Junior Research Associate

(iD) 0000-0002-8883-1284. E-mail: mesheznikoff@yandex.ru

(c) KalmSC RAS, 2020

(C) Mesheznikov A. V., 2020

\begin{abstract}
Introduction. The collection of Sanskrit manuscripts of the Lotus Sutra is a richest one in the Serindian Collection of the Institute of Oriental Manuscripts (RAS, 27 call numbers). Most of the fragments of the Sanskrit Lotus Sutra from the Serindian Collection belong to the Central Asian edition, including the famous Kashgar manuscript by N. F. Petrovsky that is the most extensive version of the Sutra (about 400 folios) and the core of the Sanskrit manuscripts containing the text of 'Saddharmapundarika'. Most of the Sanskrit manuscripts of the Lotus Sutra in the Serindian Collection were compiled in the southern oases of the Tarim Basin and made in pothi format. The texts of these manuscripts were written in Southern Turkestan Brāhmī in black ink on paper. According to paleographic data, these manuscripts can be dated to the $8^{\text {th }}-9^{\text {th }}$ centuries AD. Goals. The article seeks to introduce into academic circulation a new fragment of the Sanskrit Lotus Sutra from the Serindian Collection of the IOM (RAS). The new unpublished fragment of the Lotus Sutra stored under call number SI 6584 has been identified relatively recently. It is an excerpt from Chapter XVIII of the Lotus Sutra ('The Chapter Describing the Religious Merit [Obtained through] Joyful Participation [in Dharma]', 'Anumodanāpunyanirdeśaparivartaḥ'). According to paleographic and codicological characteristics, the new fragment is very close to another previously published manuscript of the Lotus Sutra stored in the Serindian Collection under call number SI 1934. The article describes the external features of both manuscripts (SI 1934 and SI 6584), transliterates, translates and compares fragment SI 6584 to the other well-known texts of the Lotus Sutra. The paper also contains a facsimile reproduction of fragment SI 6584. Conclusions. As compared to other texts of the Lotus Sutra, fragment SI 6584 belongs to the Central Asian edition of 'Saddharmapundarīka', and its text is almost identical to that of the Kashgar manuscript by N. F. Petrovsky (fol. 335b-337a).

Keywords: Buddhism, Sanskrit manuscripts, Lotus Sutra, Khotan, Serindian collection.

For citation: Mesheznikov A. V. New Fragment of Sanskrit Saddharmapuṇụarīka Sūtra from Khotan. Oriental Studies. 2020. Vol. 13(3): 620-628.(In Russ.). DOI: 10.22162/2619-0990-202049-3-620-628
\end{abstract}

\section{Введение}

В собрании Института восточных рукописей РАН (ИВР РАН; бывш. Азиатский музей) сохранилось значительное количество листов и фрагментов санскритской
Лотосовой сутры («Saddharmapuṇụarīka sūtra»). На сегодняшний день выявлено 27 рукописей «Саддхармапундарика-сутры». Большинство из них представлено в коллекции Н. Ф. Петровского: SI 1925/27 (P/5); SI 
1933 (P/7); SI 1934 (P/8); SI 1935 (P/9); SI 1936 (P/9-1); SI 1937 (P/10); SI 1938 (P/11); SI 1939 $(\mathrm{P} / 11-1)$; SI $1940(\mathrm{P} / 12, \mathrm{P} / 13)$; SI 1941 (P/204); SI 2077 (P/62a); SI 2092 (P/67-2); SI 2093 (P/67-3); SI 2098 (P/67-8); SI 3000 (P/67-10); SI 3013 (P/68); SI 3025 (P/74); SI 3030 (P/79); SI 3044 (P/90a, P/90б); SI 3631 (P/126a); SI 3693 (P/151-1); SI 3694 (P/151-2).

Несколько фрагментов также хранится в коллекциях М. И. Лаврова (SI 3330 (L/1); 3332/3 (L/12)) и С. Ф. Ольденбурга (SI 4645 (O/12-1)). В коллекции С. Е. Малова сутра представлена двумя единицами хранения: SI 4517 (M/16-3) и SI 4519 (M/17). Среди перечисленных списков представлены обе версии сутры с преобладанием центральноазиатской ${ }^{1}$.

Целью данной статьи является введение в научный оборот недавно идентифицированного фрагмента Лотосовой сутры на санскрите из Сериндийского фонда ИВР РАН. В статье вниманию читателя предлагается описание и сравнение палеографических характеристик двух рукописей Лотосовой сутры (SI 1934 и SI 6584), транслитерация и перевод с санскрита на русский язык текста нового фрагмента «Саддхармапундарика-сутры» (SI 6584), а также сопоставление текста нового фрагмента с другими известными текстами сутры.

C конца XIX в. в Азиатский музей начали поступать обнаруженные в Центральной Азии письменные памятники буддизма, в числе которых имелись рукописи, содержащие санскритские фрагменты Лотосовой сутры. Сложение петербургской коллекции санскритских рукописей происходило благодаря экспедиционной деятельности в оазисах Великого шелкового пути, а также за счет материалов, которые были получены при содействии русских должностных лиц в Центральной Азии. Ключевую роль в деле собирания рукописей сыграл генеральный консул в Кашгаре Н. Ф. Петровский, который присылал в Петербург рукописи, приобретенные им у местных охотников за кладами и торговцев. В 1893 г. в Азиатский музей была доставлена уникальная находка - Лотосовая сутра на санскрите, которая позднее получила широкую на-

${ }^{1}$ В настоящее время принято считать, что существует две версии Лотосовой сутры: центральноазиатская и гильгитско-непальская [Памятники 1985: 79]. учную известность как кашгарская рукопись Н. Ф. Петровского (шифр хранения SI $1925 / 27$ (P/5)). Эта рукопись является наиболее полным из известных списков «Саддхармапундарика-сутры». В ней насчитывается около 500 листов, 396 из которых хранятся в ИВР РАН. В других хранилищах мира обнаружено всего 56 листов, 12 листов сутры до сих пор не найдено [Памятники 2004: 84].

Кашгарская рукопись Н. Ф. Петровского является одним из основных материалов для исследования Лотосовой сутры в целом и ее центральноазиатской версии в частности. При сопоставлении текста кашгарской рукописи с публикуемым фрагментом были использованы факсимильное издание Локеша Чандры [Chandra 1977] и текст в виде транслитерации латиницей, изданный Хирофуми Тодой [Toda 1981].

В рукописном фонде ИВР РАН под шифром SI 6584 хранится фрагмент «Саддхармапундарика-сутры» из Хотана, который удалось идентифицировать сравнительно недавно. Согласно надписи на конверте рукописи публикуемый фрагмент относится к коллекции С. Е. Малова, однако есть основания полагать, что его следует включить в состав коллекции Н. Ф. Петровского. Весьма вероятно, что этот новый фрагмент и ранее опубликованная рукопись сутры SI 1934 [Памятники 1985: 137-139, 254-256] принадлежат к одному и тому же списку «Саддхармапундарика-сутры». На это указывают схожие внешние характеристики рукописей: особенности бумаги, число строк и расстояние между ними, тип письма, дукт, размер акшар и др.

\section{Описание рукописей}

Рукопись, хранящаяся под шифром SI 1934, включает три листа формата потхи. Размер листов - 8,5×34,5 см; 8,7×34,3 см; $8,6 \times 25,3$ см. Текст на обеих сторонах листов нанесен черной тушью, на каждой стороне по 6 строк. Расстояние между строками составляет 1,4 см. Бумага светло-коричневого цвета, вержированная, 7 линий верже в 1 см. Текст записан южнотуркестанским брахми. Условная датировка рукописи VIII-IX вв.

Рукопись, хранящаяся под шифром SI 6584, включает один лист формата потхи. Размер листа - 9,1 × 31,6 см. Текст нанесен 
черной тушью на бумагу светло-коричневого цвета. Бумага вержированная (7 линий в 1 см). Левый и правый края утрачены, тушь местами сильно стерлась. Текст написан на обеих сторонах листа, на каждой стороне по 6 строк. Расстояние между строками 1,4 см. Письмо - южнотуркестанское брахми. По палеографическим данным рукопись датируется VIII-IX вв.

Теоретически одну и ту же рукопись могли переписывать несколько человек, и, поскольку в рассматриваемых фрагментах наблюдается достаточно высокий уровень каллиграфии, можно предположить, что, даже если тексты были записаны разными людьми, они принадлежали к одной школе писцов. На это указывают идентичные числовые характеристики толщины линий и размеров акшар в рукописях SI 1934 и SI 6584.

Для измерения средней высоты и ширины акшар были выбраны элементы наиболее часто встречающихся в рукописях акшар $t a$, $n a, p a, y a$. Условная высота акшары замерялась по высоте крайнего правого элемента акшары $р а$ и составила в обеих рукописях около 4,2 мм. В случае с шириной измерялись две величины: стандартная ширина акшары (по верхней горизонтальной линии акшар ta и $n a$ ) и максимальная ширина акшары (по верхним крайним точкам акшары $y a)$. Средние параметры ширины акшар $t a$ и $n a$ распределились в диапазоне от 7 до 8 мм, акшары $y a$ - от 12,5 до 13,5 мм. Кроме того, при измерении толщины линий диакритического знака $\bar{a}$ удалось установить, что размер носика калама в обеих рукописях одинаковый - 1 мм² $^{2}$

Таким образом, листы рукописей имеют ряд сходных черт, из чего можно сделать предположение, что либо они представляли одну рукопись, либо были взяты из разных рукописей, но написаны в одной рукописной мастерской.

Если допустить, что SI 1934 и SI 6584 представляют собой одну рукопись, то едва ли можно предположить, что Н. Ф. Петровскому и С. Е. Малову данная рукопись была продана по частям, поскольку известно, что С. Е. Малов приобрел свою хотанскую коллекцию с рукописями письмом брах-

\footnotetext{
${ }^{2}$ Все полученные числовые показатели следует считать приблизительными и усредненными.
}

ми в 1915 г., то есть со времени последних приобретений Н. Ф. Петровского прошло порядка десяти лет. Предположительно, публикуемый фрагмент был включен в состав коллекции С. Е. Малова по ошибке.

Рукопись SI 6584 представляет собой отрывок из XVIII главы «Саддхармапундарика-сутры» ('Глава, повествующая о религиозных заслугах, [обретаемых благодаря] радостной сопричастности [Дхарме]', «Anumodanāpuṇyanirdeśaparivartaḥ»). Содержание главы кратко сводится к следующему. Бодхисаттва Майтрейя спрашивает Будду, что обретет человек, который услышит Лотосовую сутру и с радостью ей последует. По словам Будды, принятие учения Лотосовой сутры принесет адепту неисчислимые религиозные заслуги и обеспечит лучшее перерождение. Даже пятидесятый по очереди человек, услышавший хотя бы одну гатху из Лотосовой сутры и воспринявший ее Дхарму, станет обладателем безграничных достоинств. ${ }^{3}$

Ключевой для данной главы и входящий в состав ее названия термин anumodanā вплоть до настоящего времени не обрел концептуального толкования ни в отечественной, ни в зарубежной буддологии. Слово anumodanā буквально переводится как «выражение благодарности, удовлетворения или одобрения» [Edgerton 1953: 32], «угождение, признание, принятие, сорадование» [Monier-Williams 1899: 37].

Однако в указанных значениях не в полной мере раскрывается специфическое содержание, которым в Лотосовой сутре был наделен этот термин, ибо в данном контексте anumodanā следует понимать как радостную сопричастность знанию. Как явление махаянского буддизма anumodanā сопоставляется в этой главе сутры с практиками классического буддизма. Благодаря слушанию Лотосовой сутры человек испытывает радостную сопричастность заложенной в ней истине, которую постиг Будда, и которую постигает сам слушатель.

В главе подчеркивается, что с точки зрения накопления религиозной заслуги

${ }^{3}$ Вероятно, имеется в виду, что проповеди Будды, распространяясь, достигнут пятидесятого по очереди человека, и даже блага этого пятидесятого человека будут неисчислимыми, если он, услышав хотя бы одну строку Лотосовой сутры, испытает радость от сопричастности к заключенному в ней знанию. 
anumodanā превышает практику даяния и принцип архатства. Радостная сопричастность, обретаемая посредством слушания сутры, не сравнима ни с общедоступной практикой для мирян, ни с йогической практикой и превосходит все имеющиеся способы совершенствования. Термин anumodanā встречается также и в других махаянских текстах, таких как Așțasāhasrikā Prajñāpāramitā Sūtra («Сутра запредельной мудрости в 8000 строф») [Vaidya 1960] и Mahāparinirvāṇa Sūtra («Сутра о Великой Нирване») [Waldschmidt 1950]. Краткое описание семантики anumodanā дает только общее представление об этом термине, требующем в дальнейшем более детального анализа.

\section{Заключение}

Сопоставление с известными текстами Лотосовой сутры показало, что публикуемый фрагмент ближе всего к центральноазиатской редакции «Саддхармапундарика-сутры» ${ }^{4}$. Основные отличия двух редакций сутры состоят в том, что центральноазиатский текст содержит значительно больше повторений, нежели гильгитско-непальские. В кашгарской рукописи Н. Ф. Петровского насчитывается 28 глав, тогда как в непальских и гильгитских рукописях их 27: одна «лишняя» глава, как указывает М. И. Воробьева-Десятовская, появилась благодаря тому, что глава ХІ была разбита на две главы [Памятники 1985: 82].

Кроме того, по утверждению Х. Керна и Б. Нандзё, различия также встречаются в грамматических формах, синтаксических конструкциях и порядке слов в стихотворных частях. На основе грамматического анализа текстов «Саддхармапундарика-сутры» $\mathrm{X}$. Керн заключил, что центральноазиатская версия сутры, известная по кашгарской рукописи, является более оригинальной, нежели непальские тексты, в которых более грамматически выверенный язык обусловлен позднейшей обработкой и редактированием [Kern, Nanjio 1912: 9].

При всем при этом последовательность главных событий и фактов в обеих версиях

4 Критерием для отнесения фрагмента SI 6584 к центральноазиатской редакции сутры стало преимущественное сходство содержащегося в нем текста с тем, который представлен в кашгарской рукописи Н. Ф. Петровского. одинакова, тексты не различаются трактовкой буддийской догматики, а понятия буддийской доктрины идентичны [Памятники 1985: 90].

Ниже публикуется транслитерация фрагмента в сопоставлении с гильгитской рукописью из Национальных архивов Индии [Watanabe 1975], с текстом Х. Керна и Б. Нандзё из «Bibliotheca Buddhica», а также с кашгарской рукописью Н. Ф. Петровского и рукописью из коллекции А. Стейна из Кхадалика [Toda 1981: 276-277] ${ }^{5}$.

Текст публикуемого фрагмента соответствует кашгарской рукописи SI 1925/27 (л. 335b-337a), гильгитской рукописи (л. 127a (5)-127b (6)), тексту из «Bibliotheca Buddhica» (л. 348-350). В рукописи из коллекции А. Стейна сохранилась только часть идентичного текста (см. Н 179(4)-Н 180(7)).

\section{Условные обозначения}

() - восстановленная акшара

[ ] - поврежденная акшара

$<>$ - пропущенная в тексте акшара и вставленная переписчиком под или над строкой

\{\} - лишняя акшара, вставленная переписчиком по ошибке

+ - утраченная акшара

.. - акшара, которую не удается прочесть

. - нечитаемая часть акшары, которую не удается реконструировать

‘ — знак аваграха (в рукописи отсутствует, но в транслитерации реконструируется)

/// - обрыв рукописи

- - обозначение пунктуации в рукописи

| - данда - обозначение пунктуации в

рукописи (конец раздела или прозаической части)

$\|$ - двойная данда - обозначение пунктуации в рукописи

* — обозначение вирама в рукописи

: - висарга как обозначение пунктуации

о — обозначение отверстия для брошюровки

5 Частично сохранившийся текст публикуемого фрагмента был обнаружен в рукописи из коллекции А. Стейна, хранящейся в Британской библиотеке под шифром Kha. IX. 42 (The British Library Stein collection). При выявлении разночтений была использована транслитерация рукописи Kha. IX. 42 в издании Хирофуми Тоды. 


\section{SI 6584}

Транслитерация

Recto

1. /// + śalābhisaṃskāraś cā[r]ha[t]v[a](p)r(a) + + + nasahagataś ca punyābhisaṃskārah śatimām a-

2. // ṭi [m]ām api koțiśatimām api koțisahasrimām api koṭiśatasahasrimām api ko- ///

3. /// (pai)ti gaṇa[n] $[\bar{a}) m$ apy upanișām api nopaiti • evāprameyam ajita • e(v). ///

4. /// .. vati • ya ito dharmaparyāyā +++ (e)kagāthām api ekapa .. ///

5. /// .ā .. [śru]tvā cānumodet* ato 'pra ++++ tasyāham punyābhisaṃs(k)ā ///

6. /// .. vā kuladuhitā vā svagrhh[ā]n niṣkramitvā vihāraṃ gac(ch)et* ///

SI 1925/27: iya-m-asya ajita punyābhisaṃskārakuśalābhi(saṃ)skārasya anumodanāsahagatasya puratah sa pūrvako dānasahagata\{m̧̧h punyābhisamskāras\{ya\} kuśalabhisamskāraś ca arhatvapratișthāpanasaha(gataś ca punyābhisamskā)rah śatamām api kalān nopaiti • sahasrimām api kal(ān ...) m api kot̄̄sahasrimām api kotūíatasa(hasrimām ... sa)hasrimām api kalān nopaiti • sa (m) khy (ām ... upanisāa)m api nopaiti • evāpramevam ajita e(vāsamkhyeyam ... pañcāśatima) kah purușah paramparāyā(h) punyam prasavati ya it(o ...) ekagāthām api ekapadam api śrutvā "numodeta kah punar vādah ajita yo mama sammukham imam dharmaparyāyam śrnayāt* śrutvā cānumodet* ato 'prameyataram tasyāham punvābhisamskāam vadāmy asamkhyeyataram yas \{ya\} khalu punar ajitemasya dharmaparyāyasya śravañārthāya kulaputro $\underline{v a}$ kuladuhitā (vā) svagrhān niskrramitvā vihäram gacchet

Kha. IX. 42: iha-m-asya ajita pu(n)yābhisamskāarakuśalābhisam (...) tāsya puratah sa pūrvako dānasahagatam (punyābhi)sa(m)sk(āra)sya (...)samskāraś ca arhatvapratișthāpanasahagataś ca punvābhisamsk $(\bar{a})$ rah śatimāa (...) kalān nopaiti $\bullet$ sahasrimām api kalān nopaiti $\bullet$ kotimām api

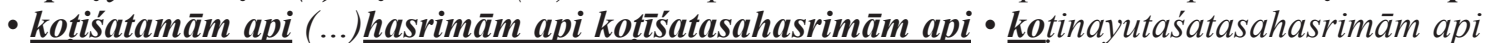
(...)paiti $\bullet$ sa (m) khyām api kalān nopaiti $\bullet$ gananām apy upanisām api nopaiti $\bullet(.$.$) prameyam$ ajita evāpramevam ajita evāsamkhyeyam sau 'pi tāvat pañcā (...) purușah paramparāyāa (h)

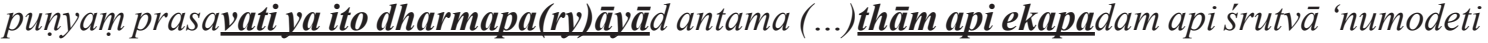
ka(h punar vādah a)ji(...) sam (mu)kha(m) imam dharma(pa)ryāyam śṣnvayāt* śrutvā ca (...)ram

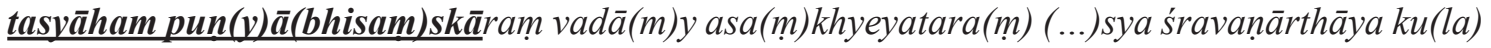

Gilgit MSS GROUP A: tasya ajita punyābhisaṃskārasya kuśalābhisaṃskāsya anumodanāsahagatasya agratah asau pūrvakah dānasahagataś caarhattvapratisthāpanāsahagaś ca punvābhisamskārah śatatamām api kalām nopayāti • sahasratamām api śatasahasratamām api koțìtamām api kotīśatatamām api kotūsahasratamām api • koținnayutaśatasahasratamām api nopayāti • samkhyām api kalām api gananām apy upamām apy uniśām api na kșamate • evam

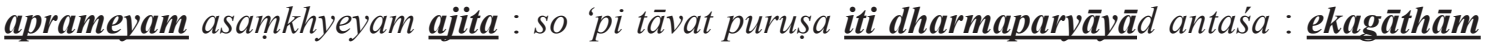
api ekapadam apy anumoditvā punyam prasavati $\bullet$ kah punar vādo jita yo mama sammmukham imam dharmaparyāyam śrrutvā anumoded aprameyataram tasyāham ajita punvābhisamskāram vadāmy asaṃkhyeyataram yah punar ajita asya dharmaparyāyasya śravan̄arrtham kulaputro $\underline{\mathbf{v}} \overline{\boldsymbol{a}}$ kuladuhitā vā svagrhā niskramya vihāram gacchet

Kern, Nanjio: asya anumodanāsahagatasya ajita punyābhisaṃskārasya kuśalamūlābhisaṃskārasya anumodanāsahagatasya agratah asau paurviko dānasahagataś ca arhattvapratisthāpanāsahagataś ca punvābhisamskārah śatatamūm api kalām nopayāti sahasratamīm api śatasahasratamìm api koțìtamìm api kotīśatatamīm api koțīsahasratamīm api kotíśatasahasratamīm api kotīnayutaśatasahasratamīm api kalām nopayāti saṃkhām api kalanām api gananām apy upamām apy upanisadam api na kșamate evam apramevam

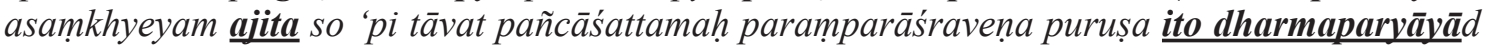
antaśa ekagāthām apvekapadamapy anumodya ca punyam prasavati| kah punar vādo 'jita yo 'yam mama sammukham imam dharmaparyāyam śrnuyācchrutvā cābhyanumodet $\mid$ aprameyataram 
asaṃkhyeyataram tasyāham ajita tạn punyābhisamskāaram vadāmi || yah khalu punar ajita asya dharmaparyāyasya śravan̄ārtham kulaputro vo kuladuhitā vā svagrhān nișkramva vihäram gacchet

\section{Verso}

1. /// (sa) ajita kulaputras tan mātra[k]eṇa puṇyābhisaṃskāre[ṇa] [k]ṛ(t)[e] ///

2. /// [lā]bhī bhavișyaty aśvarathā ++++ (th)ānāṃ śivikayānā[n]. ///

3. /// nānāṃ lābhī bhavișyati • sa[c][e] + (p) [u] + + + dharmaśravaṇe muhūrtamā[t] $\mathrm{r}(\mathrm{a})$.. ///

4. /// dāpaye(t)* āsanasaṃvibhāgaṃ ca kuryād aparasya satvasya sa tena [p]. ///

5. /// .. t[i] • ['́] akrāsanānāṃ brahmāsanānāṃ cakravartirājāsanānāṃ siṃhāsa[nā] ///

6. /// (ra)sya puruṣasyaivaṃ vaded ā $[\mathrm{g}] \mathrm{a}(\mathrm{c}) .++$ [v]at tvam bhoh puruṣa saddharmapauṇụarikaṃ nāma sūtrạ̣

SI 1925/27: sa ajita kulaputras tammātrakena punvābhisamskārena krtenopacitena jātivītivru(t)to dvitīye ātmabhāvapratilābhe gorathānām lāahō bhavisvaty aśvarathān $\bar{a}(m)$

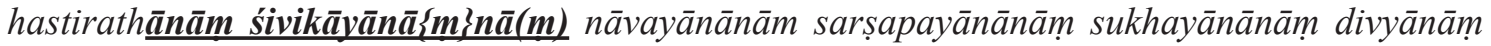

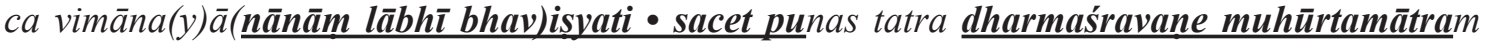
api (... dharmapa)ryāya(m) śrnuyā(t*) parasatvam vā nișidā(payed ... apara)sya satvasya sa tena paramāsana (... punyābhisamn)skāreṇa kuśalābhisamnskāreṇa lābhī bhavișya(ti ... ca krravartirājāsanānām simhāsanānām lābhī bhav(ișyati ...) ajita tatra kaścid eva puruṣạ aparasva purusasvaivam vaded ägaccha tāva(t) tvam bhoh purusa saddharmapundarīkam nāma sūtram dharmaparyāyam śṛnuṣva

Gilgit MSS GROUP A: $\underline{\text { sa }}$ sattvas tanmātrena punvābhisamskārena krtenopacitena jātivinivrtto

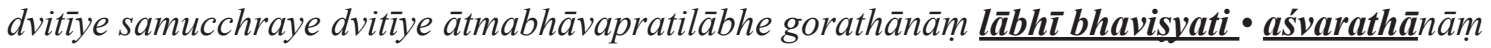

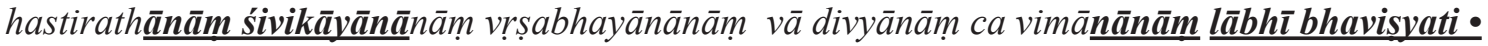
sacet pun as tatra dharmaśravanisu muhürtamātram api niṣadyemam dharmaparyāyam śrinuyāt parạ̣ vā nișādayed āsanasamvibhāgam vā kuryäd aparasya sattvasya tena punyābhisaṃskāreṇa lābhī vati • śakrāsanānām brahmāsanānām cakravartisimhāsanānām • sacet punar ajita kaścid eva kulaputro vā kuladuhitā vā aparam purusam evam vaded ăgaccha tvam bhoh purusa : saddharmapundarīkam nāma dharmaparyāyam śṛnu:

Kern, Nanjio: sa sattvastanmātrena punyābhisamskārena krtenopacitena jātivinivrtto dvitīye

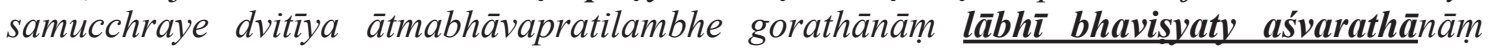

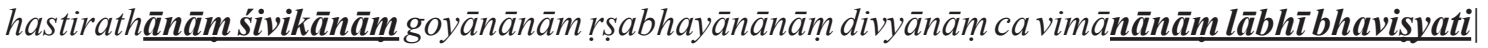
sacet punas tatra dharmaśravane muhürtamātram api nișadyemam dharmaparyāyam șrnnuyāt


lābhì bhavișyati śakrāsanānām brahmāsanānām cakravartisimhāànanānām| sacet punar ajita kaścid eva kulaputro vā kuladuhitā vä aparam purusam evam vaded ägaccha tvam bhoh purusa saddharmapundarīkam nāma dharmaparyāyam śṛnuș̣a

\section{SI 6584 (recto)}

Перевод

1-2. [прежнее] накопление заслуг, [связанное с даянием и] обретением архатства, [не стоит] даже одной сотой части, одной тысячной, одной десятитысячной доли от накопления добродетели [путем радостного принятия].

3-4. [Их] невозможно сравнить с помощью чисел и тайных знаний. Так огромна, о Аджита, так [неисчислима эта заслуга, которую обретает пятидесятый по очереди человек, услышавший] хотя бы одну гатху, одну [строку] из Лотосовой сутры

5-6. и с радостью ей последовавший. Я [заявляю, о Аджита, что] накопление заслуг 
[у того человека будет] еще более [грандиозным, более неисчислимым]. [Если юноша] или девушка из хорошей семьи [с целью услышать Лотосовую сутру,] покинув свой дом, направится в монашескую обитель,

\section{SI 6584 (verso)}

1-3. о Аджита, этот человек только благодаря накопленным [в результате этого действия] заслугам [в своем следующем рождении] станет обладателем колесниц, [запряженных] лошадьми [и слонами], паланкинов, [лодок, воздушных колесниц, легких повозок и божественных летательных кораблей]. Если человек пусть даже на одно мгновение

4-5. [сядет, чтобы послушать Лотосовую сутру], или убедит другого сесть, или поделится с ним своим местом, он [за счет заслуг, полученных в результате этого действия,] обретет место Индры, Брахмы, царя Чакравартина.

6. Если также есть человек, который скажет другим людям: «Приди и послушай Лотосовую сутру...»

\section{Факсимиле}

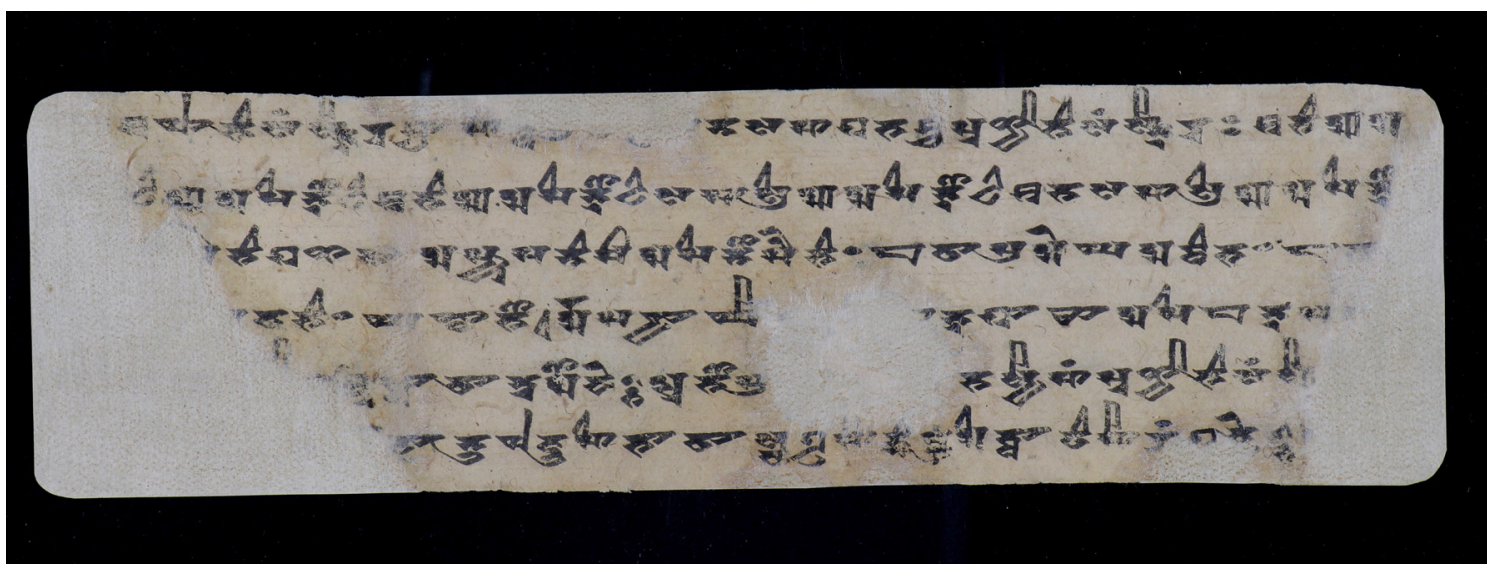

Puc. 1. SI 6584 recto

[Fig. 1. SI 6584 recto]

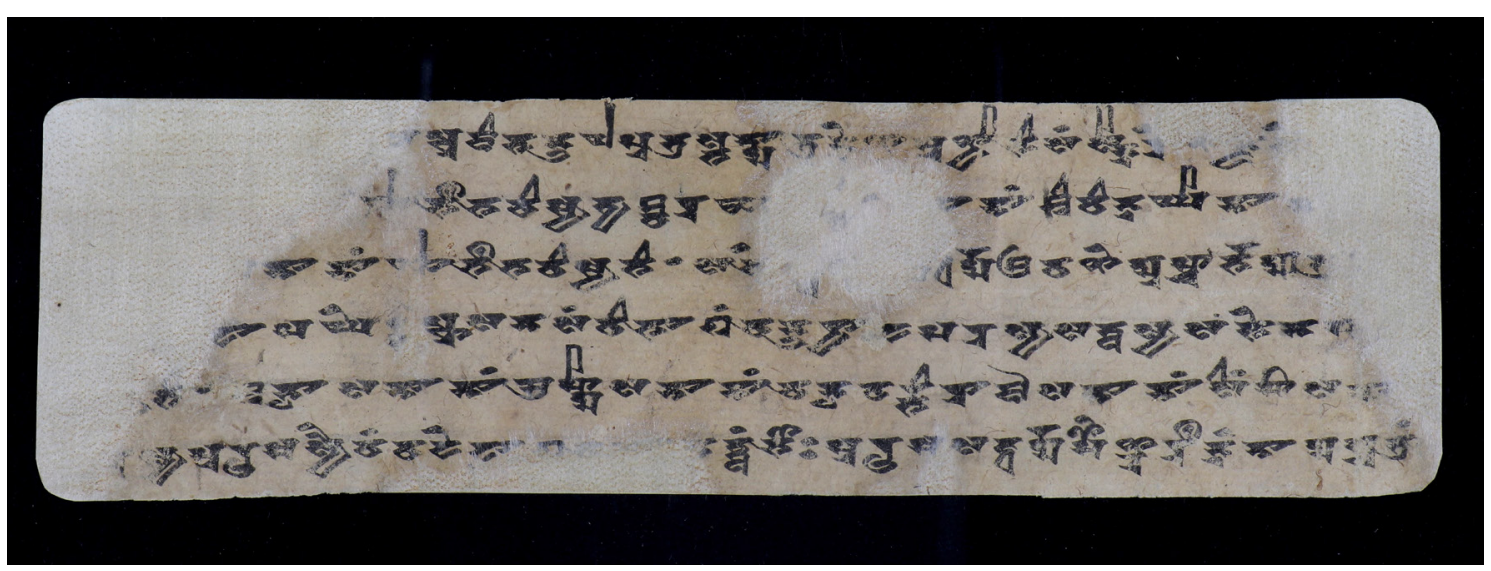

Puc. 2. SI 6584 verso

[Fig. 2. SI 6584 verso] 


\section{Литература}

Памятники 1985 - Бонгард-Левин Г. М., Воробъева-Десятовская М. И. Памятники индийской письменности из Центральной Азии. Вып. 1. М.: Наука, ГРВЛ, 1985. 288 с.

Памятники 2004 - Бонгард-Левин Г. М., Воробьева-Десятовская М. И., Тёмкин Э. Н. Памятники индийской письменности из Центральной Азии. Вып. 3. М.: Наука, Вост. лит., 2004. 585 с.

Chandra 1977 - Chandra L. Saddharmapuṇụarīka-sūtra, Kashgar Manuscript. Tokyo: The Reiyukai library. $1977.435 \mathrm{c}$.

Edgerton 1953 - Edgerton F. Buddhist Hybrid Sanskrit Grammar and Dictionary. New Haven: Yale University Press, 1953. 627 p.

Kern, Nanjio 1912 - Kern H., Nanjio B. Saddharmapuṇurāka. Bibliotheca Buddhica X. St.-Pe-

\section{References}

Bongard-Levin G. M., Vorobyova-Desyatovskaya M. I. Brahmi Script: Monuments from Central Asia. Vol. 1. Moscow: Nauka, GRVL, 1985. 288 p. (In Russ.)

Bongard-Levin G. M., Vorobyova-Desyatovskaya M. I., Temkin E. N. Brahmi Script: Monuments from Central Asia. Vol. 3. Moscow: Nauka, Vostochnaya Literatura, 2004. 585 p. (In Russ.)

Chandra L. Saddharmapuṇdarīka-Sūtra, Kashgar Manuscript. Tokyo: The Reiyukai Library, 1977. 435 p. (In Eng.)

Edgerton F. Buddhist Hybrid Sanskrit Grammar and Dictionary. New Haven: Yale University Press, 1953. 627 p. (In Eng.)

Kern H., Nanjio B. Saddharmapuṇụarīka. Biblio- tersburg: Printing house of the Imperial Academy of Sciences, 1912. 508 p.

Monier-Williams 1899 - Monier-Williams M. A Sanskrit-English Dictionary. Oxford: The Clarendon Press, 1899. 1338 p.

Toda 1981 - Toda H. Saddharmapuṇdarīka sūtra: Central Asian manuscripts. Romanized text. Tokushima: Kyoiku Shuppan Center, 1981. $368 \mathrm{p}$.

Vaidya 1960 — Vaidya P. Așțasāhasrikā Prajñāpāramitā. Darbhanga: Mithila Institute, $1960.579 \mathrm{p}$

Waldschmidt 1950 — Waldschmidt E. Das Mahāparinirvāṇasūtra, Teil I: Der Sanskrit-Text im Handschhriftlichen Refund. Berlin: Akademie-Verlag, 1950. $101 \mathrm{p}$.

Watanabe 1975 - Watanabe S. Saddharmapuṇụarīka manuscripts found in Gilgit. Tokyo: The Reiyukai library. 1975. 307 p.

theca Buddhica X. St. Petersburg: Imperial Academy of Sciences, 1912. 508 p. (In Eng.)

Monier-Williams M. A Sanskrit-English Dictionary. Oxford: The Clarendon Press, 1899. 1338 p. (In Eng. and Sans.)

Toda H. Saddharmapuṇḍarīka Sūtra: Central Asian Manuscripts. Romanized Text. Tokushima: Kyoiku Shuppan Center, 1981. 368 p. (In Eng.)

Vaidya P. Așțasāhasrikā Prajñāpāramitā. Darbhanga: Mithila Institute, 1960. 579 p. (In Sans.)

Waldschmidt E. Das Mahāparinirvāṇasūtra, Teil I: Der Sanskrit-Text im Handschhriftlichen Refund. Berlin: Akademie-Verlag, 1950. 101 p. (In Germ.)

Watanabe S. Saddharmapuṇụarīka Manuscripts Found in Gilgit. Tokyo: The Reiyukai Library, 1975. 307 p. (In Eng.) 